\title{
THE MAPPING OF RARE PLANT SPECIES DISTRIBUTION IN MONKEY FOREST, UBUD, GIANYAR, BALI
}

\author{
Nyoman Wijana, I Gede Astra Wesnawa
}

Masuk: 21032018 / Diterima: 28062018 / Dipublikasi: 30062018

(C) 2018 Fakultas Hukum dan IImu Sosial UNDIKSHA dan IGI

\begin{abstract}
The purpose of this research was to know the species of rare plants existing in forest tourism and their mapping distributions in the original nature. The populations of this research were all species of plants in Monkey Forest. The sampling method used was quadratic method with systematic sampling technique. The mapping of rare plant species distribution used simple mapping method which was simple polygon compass and GPS. Identification of rare plant species was conducted through interviews, questionnaires, observations, and document studies. The results showed that the distribution of rare plant species in Monkey Forest was in groups. The total number of rare plant species their nature were 33 species with the details that there were as many as six species of plants belonging to the National Rare category, 18 species of Bali Rare category, eight species of Regency Rare category, and one species of Rare Sub-District category.
\end{abstract}

Key words: Map; Species Distributions; Rare Plants

\section{Introduction}

There are some tourism object of forests in Bali they are tourim forests of Alas Kedaton (Tabanan), Penglipuran (Bangli), Monkey Forest (Gianyar), Sangeh (Badung), Tenganan Pegringsingan (Karangasem), Bedugul (Buleleng), and Dasong (Tabanan). This research emphasized on the tourism forest of Monkey Forest (Gianyar). Monkey Forest is a natural reserve that has approximately 340 long tailed monkeys (Macaca fascicularis). This tourism forest covers 27 hectares and 125 species of plants live in it (Wijana \& Setiawan, 2017a). Mandala Suci Menara Wana or better known as Monkey Forest is one of the most famous tourism forest areas in Bali. Monkey Forest is actually a forest area as well as a cemetery belongs to Padangtegal Village. The area of \pm 13

Nyoman Wijana, I Gede Astra Wesnawa Universitas Pendidikan Ganesha Singaraja wijana 1960@yahoo.com,

gede astrawesnawa@yahoo.co.id hectares is not known the beginning of its existence. I Nyoman Buana (personal interview, 2017) as the general manager of Monkey Forest said that based on Jaya

Pangus inscription record year 1103 Saka (1181 AD) mentioned that during the reign of King Sri Aji Jaya Pangus, Monkey Forest was already there and was the area of his hunt. Gradually the residents cleared away the forest and settled there. More and more people cleared away the forest for settlements and paddy fields.

In the process of changing the forest ecosystem into a residential ecosystem, there has been a change in the vegetation. There are some plant species that have been lost from their habitat (extinct), some live only (rare) plant species, and some plant species that are still deliberately preserved because of their economic, religious and sacred values or they are considered as sacred plants by the local community.

Several studies have been conducted by Wijana (2008, 2012, 2013, 
2014), Wijana \& Setiawan (2017a, 2017b) and, Wijana \& Sumardika $(2005,2009)$ respectively in the buffer for Lake Batur (Bangli), Lake Buyan buffer forest (Buleleng), Tenganan Pegringsingan Village (Karangasem), Penglipuran village (Bangli), Tigawasa village and Cempaga village (Buleleng), Lovina beach (Buleleng), and Penglipuran forest, Bangli. The results of the above research indicated that species diversity at the study sites generally indicated a low to moderate index of species diversity. None of the research results indicated a high index of species diversity. This means that there were certain plant species that had been categorized as rare in terms of limited density, endemic distribution, and low frequency.

In addition, from some of the studies above, there had been no in-depth study of the endangered species and the distribution of the endangered species, which are still alive in the natural world. Meanwhile, the rare plant species in the field are difficult to detect, their distribution spots are unknown. Therefore, this study was conducted to determine the spread of the rare plant species existing in Monkey Forest, Ubud, Gianyar, Bali. The results of the rare plant species distribution was further mapped so that the position of their point can be clearly known.

\section{Method}

This research was an explorative research which explored the rare plant species in Monkey Forest, Gianyar Regency. There were 3 populations of this research namely (1) the mapping area, (2) the species of rare plants, and (3) the socioculture. The samples of this research were (1) the mapping area covering the whole forest area, (2) the rare plant species covered by squares with $20 \times 20 \mathrm{~m}$ of 172 squares, (3) socio-cultural samples including the village officials (5 people), the traditional village officials (5 people), community leaders (10 people), and the general public (10 people). The total was 30 people.

The method of mapping is done by simple measurement techniques referring to Soenaryanto (1976) and Teten \& Darjo (1999). The data collection of the rare plant species were carried out as follows: placing the plot (squares) on the forest area sized $20 \times 20 \mathrm{~m}$ alternately and continuosly on the left and right sided transect line of 172 squares (Barbour, Burk, \& Pitts, 1987; Cox, 1976; Mueller, Dieter, \& Ellenberg, 1974; Wijana, 2014). Between one square and the other squares was given a distance of 10 meters. Furthermore, the recording and the documentation of the observation result were done. Interviews were conducted with the local community and the community around the forest area to determine the rare plants. In addition, documentation study was done. The data analysis of the rare plant species mapping was conducted descriptively.

\section{Results and Discussion The Rare Plant Species Floristic List}

There were 33 rare plant species out of 46 plant species in Monkey Fores. The identification of these rare plant species was done by interviewing the local community, the Monkey Forest management, the village officials, the academics, and by using some document references such as the Forest Service of Dati I Province of Bali in 1992, Director General of Forestry Planning (2010). Some documents which are related to rare plants, also some researches on rare plants in Indonesia, especially in Bali were also used to help the identification. Some books were also used as guidelines such as the book of rare plant inventory and preservation by Sarna (1993), the book of Environmental Sciences by Heyne (1987) and Wijana (2014). The list of those rare plant species is shown in Table 1. 
Table 1. The List of Rare Plant Species and The Rarity Level

\begin{tabular}{|c|c|c|c|c|c|}
\hline \multirow[b]{2}{*}{ No } & \multicolumn{2}{|c|}{ Plant Species Name } & \multirow[b]{2}{*}{ Family } & \multirow[b]{2}{*}{$\begin{array}{c}\text { Total } \\
\text { Individual }\end{array}$} & \multirow[b]{2}{*}{ Status } \\
\hline & $\begin{array}{c}\text { Local Name/ } \\
\text { Indonesian } \\
\text { Name }\end{array}$ & Scientific Name & & & \\
\hline 1. & $\mathrm{Ae}$ & Ficus racemosa & Moraceae & 29 & LB \\
\hline 2. & Aren & Arenga pinnata & Arecaceae & 8 & LB \\
\hline 3. & Bayur & $\begin{array}{l}\text { Pterospermum } \\
\text { javanicum }\end{array}$ & Streculiaceae & 2 & LN \\
\hline 4. & Bentawas & Wrightia pubescens & Vitaceae & 16 & LB \\
\hline 5. & Bentenu & Listea glutinosa & Lauraceae & 12 & L.Kab \\
\hline 6. & Beringin & Ficus benyamina & Moraceae & 16 & LB \\
\hline 7. & Bodhi & Ficus religiosa & Moraceae & 2 & L.Kab \\
\hline 8. & Boni & Antidesma bunius & Euphorbiaceae & 12 & LN \\
\hline 9. & Bunut & Ficus altissima & Moraceae & 4 & LB \\
\hline 10. & Cempaka & Michelia champaka & Magnoliaceae & 7 & LB \\
\hline 11. & Gatep & Inocarpus edulis & Fabaceae & 2 & LB \\
\hline 12. & Genitri & $\begin{array}{l}\text { Elaeocarpus } \\
\text { sphaericus }\end{array}$ & Elaeocarpaceae & 16 & LB \\
\hline 13. & Gintungan & Bischofia javanica & Phyllanthaceae & 25 & LB \\
\hline 14. & Intaran & Azadirachta indica & Meliaceae & 3 & L.Kab \\
\hline 15. & Irun & Adenanthera pavonia & Fabaceae & 6 & L.Kec \\
\hline 16. & Jempinis & Melia azedarach & Meliaceae & 3 & LB \\
\hline 17. & Kacret & Ficus superba & Moraceae & 2 & L.Kab \\
\hline 18. & Kepohpoh & $\begin{array}{l}\text { Buchanania } \\
\text { arborescens }\end{array}$ & Meliaceae & 7 & LB \\
\hline 19. & Kepundung & Baccaurea racemosa & Phyllanthaceae & 46 & LB \\
\hline 20. & Keresek & Ficus rumphi & Moraceae & 4 & L.Kab \\
\hline 21. & Kutat & Planchonia valida & Lecythidaceae & 13 & LB \\
\hline 22. & Madangan & Eugenia densiflora & Apocynaceae & 1 & L.Kab \\
\hline 23. & Majapahit & Aegle marmelos & Rutaceae & 3 & L.Kab \\
\hline 24. & Majegau & $\begin{array}{l}\text { Dysoxylum } \\
\text { densiflorum }\end{array}$ & Meiaceae & 41 & LN \\
\hline 25. & Nyantuh & Palaquium rostratum & Moraceae & 4 & LB \\
\hline 26. & Pangi & Pangium adule & Achariaceae & 7 & LB \\
\hline 27. & Pule & Alstonia scholaris & Apocynaceae & 21 & LN \\
\hline 28. & Pungut & Streblus asper & Meliaceae & 3 & LN \\
\hline 29. & Sentul & Sandroricum koetjape & Meliaceae & 8 & LB \\
\hline 30. & Siut & Syzygium polyanthum & Apocynaceae & 2 & L.Kab \\
\hline 31. & Sonokeling & Dalbergia latifolis & Fabaceae & 6 & LN \\
\hline 32. & Taep & Artocarpus elastic & Moraceae & 46 & LB \\
\hline 33. & Kemiri & Aleurites moluccana & Euphorbiaceae & 1 & LB \\
\hline
\end{tabular}

Note :

LN: National Rare reserved (PPRI No. 7 Year 1999). LB: Bali Rare reserved (PPRI No. 7 Year 1999, Rare Known in Bali according to Bali Forestry Service 1987, Rare Known in Bali Based on Bali Dati I Forestry Service 1992) L.Kab: District Rare. L.Kec: Sub-District Rare 
Based on Table 1 there were 33 rare plant species in Monkey Forest. 6 of them were categorized as National Rare. National Rare means that the plant species is nationally categorized as endangered plants. It also means that locally, from the village level to the province level, those plants are endangered. 18 plant species of them were Bali Rare. These plants were included in province rare level which means nationally they are not endangered meanwhile locally they are. Eight plant species of those 33 were categorized as District Rare. It means they are endangered from the village level to the district level. However, on the provincial and national level, they are not endangered. One plant species are categorized as Sub-District Rare. It means this species rarity is only on the subdistrict level, meanwhile on the higher stages, it is not an endangered species.

\section{Floristic Distribution Mapping of Rare Plant Species}

The distribution mapping of rare plant species in Monkey Forest is shown in Figure 1. On square 1 there were rare plant species such as bentawas, kacret, sentul. On square 3 there were rare plant species of bentawas, bentenu. On square 4 there was a rare plant species namely bentenu. On square 5 there were rare plant species such as bentawas, bentenu, jempinis. On square 8 there was a rare plant species which was irun. On square 12 there was also rare plant species of irun. On square 17 there was a rare plant species of bentawas. On square 18 there were rare plant species sch as cempaka, gintungan, teep. On square 19 there was a rare plant species, it was pangi. On square 24 there were rare plant species of gintungan, taep.

On square 31 there were rare plant species of bentawas, majegau. On square 32 there was a rare plant species of pule.
On square 38 there was a reare plant species of aren. On square 39 there was a rare plant species of bentawas. On square 40 there was a rare plant species of kemiri. On square 41 there were a rare plant species of bunut, gatep, pangi. On square 43 there was a rare plant species of gatep. On square 46 there was a rare plant species of keresek. On square 47 there was a rare plant species of siut. On square 48 there were rare plant species of kepohpoh, majegau.

On square 49 there were rare plant species of boni, taep. On square 50 there were rare plant species of genitri, kutat, pungut. On square 51 there were rare plant species of pule, bunut, kutat. On square 55 there were rare plant species of bodhi, taep. On square 56 there was a rare plant species of majegau. On square 58 there were rare plant species ae, pungut, taep. On square 60 there was a rare plant species of taep. On square 61 there were rare plants species of boni, gintungan. On square 65 there were rare plant species of beringin, kepohpoh, majegau. On square 66 there were rare plant species of bunut, cempaka.

On square 67 there were rare plant species of nyantuh, taep. On square 70 there was a rare plant species of taep. On square 72 there were rare plant species of cempaka, keresek. On square 74 there were rare plant species of kepundung, kepohpoh, taep. On square 75 there were rare plant species of beringin, kepohpoh. On square 78 there was a rare plant species of ae. On sqare 79 there was a rare plant species of keresek. On square 80 there were rare plant species of aren, sonokeling.

On square 81 there was a rare plant species of sonokeling. On square 82 there were rare plant species of genitri, kepundung. On square 87 there was a rare plant species of beringin. On square 88 there were rare plant species of bentawas, boni, gintungan, sentul. On 
square 89 there were rare plant species of gintungan, kepundung. On square 90 there were rare plant species of ae, genitri, gintungan. On square 92 there was a rare plant species of ae. On square 93 there was a rare plant species beringin. On square 94 there were rare plant species of kepundung, sentul, taep. On square 95 there was a rare plant species of genitri. On square 96 there were rare plant species of genitri, kepundung, kutata, taep. On square 97 there was a rare plant species of kepundung. On square 98 there were rare plant species of majegau, taep.

On square 100 there were rare plant species of bunut, gintungan, taep. On square 102 there were rare plant species of Pada ae, beringin, kepohpoh. On square 103 there was a rare plant species of boni. On square 105 there was a rare plant species of beringin. On square 106 there were rare plant species of kepundung, kutat, majegau, nyantuh, boni. On square 107 there were rare plant species of genitri, kepundung, gintungan, taep. On square 109 there was a rare plant species of taep. On square 110 there were rare plant species of genitri, kepundung, taep, majegau. On square 111 there were rare plant species of gintungan, kepundung. On square 114 there was a rare plant species of beringin.

On square 116 there were rare plant species of boni, kepundung, majegau. On square 119 there were rare plant species of kepundung, majegau. On square 120 there were rare plant species of beringin, gintungan, kepundung. On square 121 there were rare plant species of kepundung, taep. On square 124 there were rare plant species of ae, bayur.

On square 125 there were rare plant species of kepundung, majegau. On square 128 there were rare plant species of genitri, kepohpoh. On square 129 there was a rare plant species of beringin. On square 130 there was a rare plant of kepundung. On square 131 there were rare plant species of gintungan, sentul. On square 132 there were rare plant species of gintungan, taep. On square 133 there were rare plant species of beringin, ae, boni, genitri, gintungan. On square 134 there were rare plant species of ae, boni, and gintungan.

On square 135 there were rare plant species of ae, genitri, gintungan, majegau. On square 136 there were rare plant species of ae, nyantuh. On square 137 there were rare plant species of beringin, pule. On square 140 there were rare plant species of ae, genitri, majegau, pule. On square 141 there were rare plant species of kepundung, majegau. On square 142 there were rare plant species of ada boni, gintungan. On square 143 there were rare plant species of gintungan, kepundung, nyantuh, taep. On square 144 there were rare plant species of genitri, kepundung, kutat, pule, sentul, taep. 


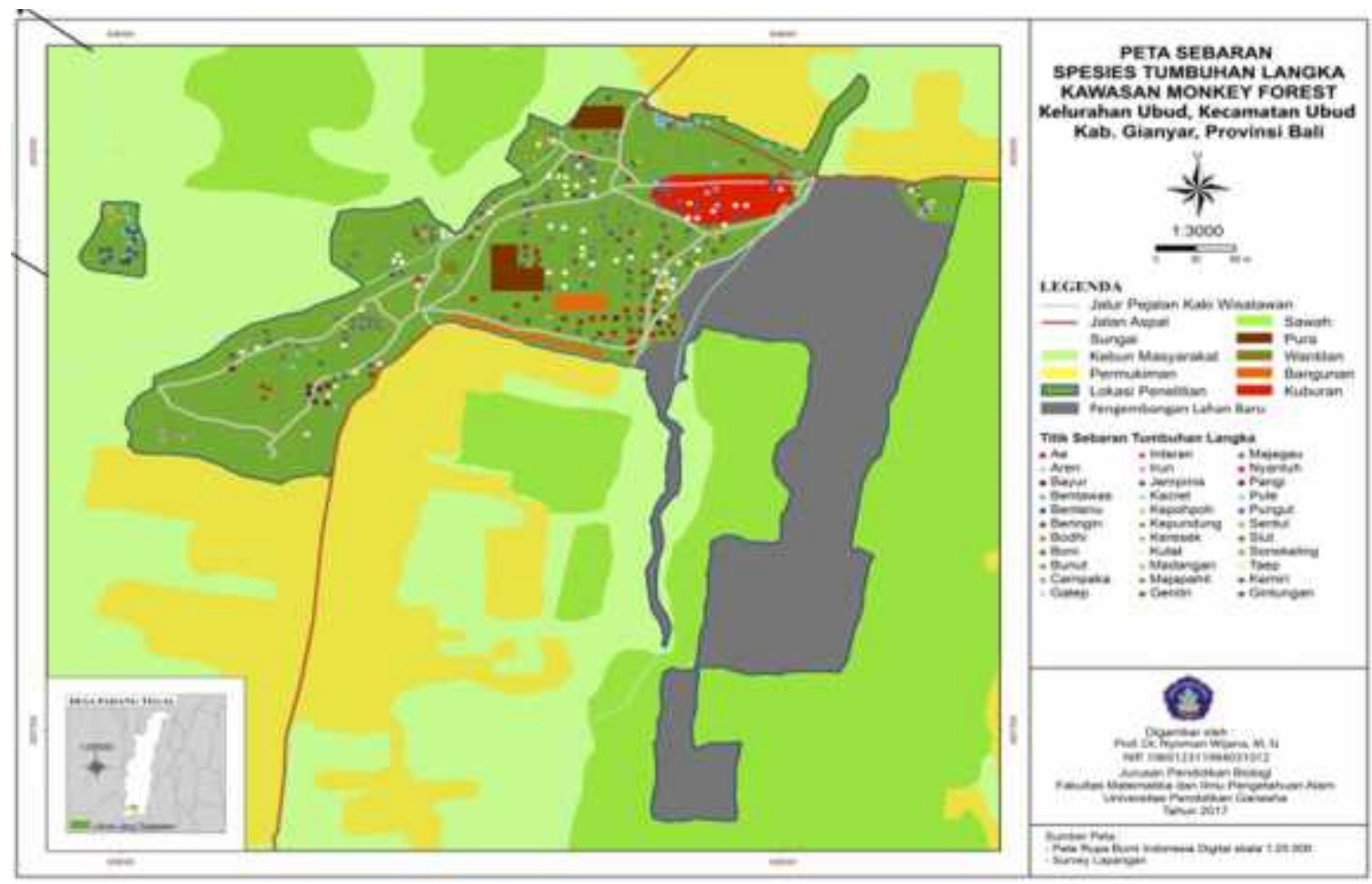

Figure 1. The Map of Rare Plant Species Distribution in Hutan Monkey Forest, Ubud, Gianyar, Bali

On square 145 there were rare plant species of ae, genitri, majegau, taep. On square 146 there were rare plant species of ae, gintungan, taep. On square 151 there was a rare plant species of pule. On square 155 there were rare plant species of gintungan, majegau, kutat, taep. On square 156 there were rare plant species of gintungan, kepundung. On square 157 there were rare plant species of pule, taep. On square 158 there were rare plant species of genitri, kepundung, majegau, sentul, taep. On square 159 there was a rare plant species of beringin. On square 160 there was a rare plant species of pule.

On square 161 there was a rare plant species of beringin. On square 163 there were rare plant species of gintungan, taep. On square 164 there was a rare plant species of boni. On square 166 there were rare plant species of boni, kutat, pungut. On square 167 there were rare plant species of cempaka, beringin, bunut, kacret, pule, pungut. On square
168 there were rare plant species of $a e$, beringin, pungut.

On square 169 there were rare plant species of ae, madangan, pungut. On square 170 there were rare plant species of bentenu, boni, cempaka, taep. On square 171 there were rare plant species of cempaka, majapahit. On square 172 there were rare plant species of irun, jempinis, majapahit, pule. There are some squares that are not mentioned due to the absence of rare plants in them.

There were 33 species of rare plants grown in the Forest Tourism Monkey Forest, where they belong to the extinct, precarious, prone, rare, and eroded according to Lucas \& Synge (1978). There were several categories of rare plants in accordance with the scarcity of the plant. There were 6 species of plants with the category LN (National Rare), where LN is a rare plant that has been threatened its existence and little found throughout Indonesia and protected by law (PPRI No. 7 of 1999). This is due to the difficulty of plants to adapt, low 
reproduction rates and massive exploitation in the absence of reforestation.

In addition to national rare, there were 18 species of plants including LB (Bali Rare) category, where LB is a rare plant that has been threatened with extinction and is little found throughout Bali and protected by law (PPRI No. 7 of 1999), a rare plant that is already known in Bali according to the Provincial Forestry Service of Bali in 1987, rare in Bali according to the Forest Service Dati I Province of Bali in 1992. The scarcity of the plant species is due to the difficulty of these plants to adapt the environment and human activities. The plants that have high economic value will continue to be developed so that the forests belonging to the communities that initially overgrown with a variety of plant species are replaced into several types of species that have high economic value. This may lead to the gradual eroding of plants with low economic value.

There were 8 species of plants that were categorized as L. Kab (District Rare), where L. Kab is a rare plant that has been threatened with extinction and little found in Gianyar regency. The cause of the scarcity of plants is because the difficulty of these plants to adapt the environment and human activities where the fewer the forests that exist, the fewer places for trees to live. Moreover, tree planting done by the community is usually only on trees that have high economic value, and the type of the plants are not much.

There was 1 species of rare plants categorized as L. Kec (Sub-District Rare), where $\mathrm{L}$. Kec is a rare plant that has been threatened its existence and little found in Ubud District. Mr. I Made Nama (private interview, 2017) said the cause of rare plant species in Ubud sub-district was that the plants had a very little economic value. Besides, the only forest in Ubud subdistrict is Monkey Forest.

The plants that live in Monkey Forest have a high diversity. Generally the diversity is caused by two factors; they are external factor and internal factor. The environmental factor (external factor) is affected by the ecological conditions in an area. This affects the plants ability to multiply themselves and to expand their distributions. This is because ecology is a reciprocal relationship between organisms, as well as between the organisms with their environment. The environment in this sense is all the external conditions and all the factors affecting the live and the development of the plants in an area, as explained by Polunin (1990). Therefore, environmental factor is very influential on the distribution of rare plants. The environmental factors (external factors) that can affect the plants growth are water, humidity, temperature, light and soil $\mathrm{pH}$, as explained by Wijana (2014).

The environmental factors in terms of biotics such as factors caused by living creatures such as human, animals or plants can be one of the limitations for plants to spread widely, according to Polunin (1990). In Monkey Forest biotics factor which has a high role is the monkeys (Macaca fascicularis). Indirectly, the monkeys help the distribution process of the plant species to become wider on a close or even on a distant area by the fruits or seeds they cast or move. On the other hands, the monkeys may also complicate the plants distribution especially the plants that produce fruits which are favored by the monkeys. Those monkeys will eat the fruits, besides they love to play around, the newly growth plants will die trampled by them.

\section{Conclusions}

From this research results can be concluded that the rare plant species in Monkey Forest, Ubud, Gianyar, Bali were distributed in clusters. The total of the rare plant species in their nature were 33 species with details that 6 of them were categorized as National Rare, 18 plant species were Bali Rare, 8 plant species were District Rare and one plant species were categorized as Sub-District Rare. 
From the conclusion above it can be recommended that those rare plant species must be reserved in their nature. In a long term, those rare plant species in their nature can be used as an alternative tourism object.

\section{Reference}

Barbour, M. G., Burk, J. H., \& Pitts, W. D. (1987). Terrestrial Plant Ecology. California: The Benjamin/Cummings Publishing Company.

Cox, G. . (1976). Laboratory Manual of General Ecology. United States of America: WM. C. Brown Company Publisher.

Heyne, K. (1987). Tumbuhan Berguna Indonesia I-IV. Jakarta: Yayasan Sarana Wana Jaya.

Lucas, G., \& Synge, H. (1978). The IUCN Plant Red Data Book: Comprising Red Data Sheets on 250 Selected Plants Threatened on A World Scale. International Union for Conservation of Nature and Natural Resources.Threatened Plants Committee.

Mueller, D., Dieter, \& Ellenberg, H. (1974). Aims and Methods of Vegetation Ecology. New York: John Willey \& Sons.

Polunin, N. (1990). PengantarGeografi Tumbuhan dan Beberapa IImu Serumpun. (Gembong Tjitrosoepomo, Ed.). Yogyakarta: Gajah Mada University Press.

Soenaryanto, R. P. (1976). Catatan Pemetaan Sederhana Peta dan Tata Batas. Bogor: Pusat Pendidikan dan Latihan Kehutanan.

Teten, E., \& Darjo, U. S. (1999). Polygon Kompas. Kadipaten: PelatihanPengukuranTerrestris. Angkatan IV BalaiLatihanKehutanan.

Wijana, N. (2008). Keanekaragaman Spesies Tumbuhan, Manfaat dan Upaya Pelestariannya. Jurnal Matematika Dan Sains, 5(10), 17-34.

Wijana, N. (2012). Analisis Dampak Lingkungan Dan Upaya Pengelolaan Berbasis Ergologi Kawasan Wisata Lovina, Buleleng, Bali.

Wijana, N. (2013). Analisis Vegetasi Hutan Adat, Upaya Pengelolaan Berbasis
Kearifan Lokal dan Pemberdayaan Masyarakat Melalui Pendekatan Ergologi di Desa Bali Aga Buleleng, Bali.

Wijana, N. (2014). Analisis Komposisi dan Keanekaragaman Spesies Tumbuhan di Hutan Desa Bali AgaTigawasa, Buleleng, Bali. Jurnal Sains Dan Humaniora, 1(1), 55-65.

Wijana, N., \& Setiawan, I. G. A. N. (2017a). The Formation Of Mini Illustrated Dictionary Of Rare Plants In The Village Forest Of Penglipuran, Bangli, Bali. In ICONMS. Bali: FMIPA Universitas Pendidikan Ganesha.

Wijana, N., \& Setiawan, I. G. A. N. (2017b). The Mapping of Rare Plant Species Distribution and The Distribution Pattern in The Village Forest of Penglipuran, Bangli, Bali. In ICIRAD. Bali: Universitas Pendidikan Ganesha.

Wijana, N., \& Sumardika, I. N. (2005). Analsis Vegetasi Hutan Bukit Kangin Desa Adat Tenganan Pengringsingan, Kabupaten Karangasem.

Wijana, N., \& Sumardika, I. N. (2009). Pelestarian Jenis-Jenis Tumbuhan Berguna Melalui Kearifan Lokal di Desa Adat Tenganan Pegringsingan, Kabupaten Karangasem, Bali. In Konservasi Flora Indonesia dalam Mengatasi Dampak Pemanasan Global (pp. 724-731). Kebun Raya "Eka Karya - LIPI. 